\title{
Online Teaching and Learning Under COVID-19 Pandemic; Perception of University Students in Ghana
}

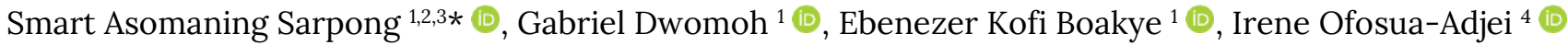

${ }^{1}$ Kumasi Technical University, GHANA

${ }^{2}$ Institute of Research, Innovation and Development - IRID, GHANA

${ }^{3}$ Centre for Social Science Research - CSSR, GHANA

${ }^{4}$ Kwame Nkrumah University of Science and Technology, GHANA

*Corresponding Author: smartsarpong2015@gmail.com

Citation: Sarpong, S. A., Dwomoh, G., Boakye, E. K., \& Ofosua-Adjei, I. (2022). Online Teaching and Learning Under COVID-19 Pandemic; Perception of University Students in Ghana. European Journal of Interactive Multimedia and Education, 3(1), e02203. https://doi.org/10.30935/ejimed/11438

\begin{abstract}
Due to the COVID-19 pandemic, universities in Ghana instituted drastic interventions to support large-scale online teaching and learning. This study, therefore, examines student's participation, level of satisfaction, and related challenges in teaching and learning delivery during the Coronavirus pandemic. The study also selects significant predictors of student's e-learning perceptions. Data was collected via an online structured survey based on students from the Kumasi Technical University. In all 2000 complete responses were received and formed the basis for our analysis. The study results reveal that 197 (9.85\% of the sample) were unable to fully participate due to challenges such as lack of access devices, unreliable internet connectivity, and inability to afford the cost of internet data. It is again clear from the results that about $90.1 \%$ of students are not satisfied with e-learning and its associated challenges. From the positive perception model, students held the view that e-learning technology in the COVID19 era is positive regardless of the challenges. On the other hand, level 300 students, and Moodle VClass platform users express a high negative perception over the use of e-learning technology. It is clear from this study that further investments and contingency plans are needed to develop a resilient education system that supports electronic and distance learning and shapes the perception and acceptance of students. University managers and the Education Ministry should formulate post-COVID-19 strategies to promote e-learning in a developing country like Ghana.
\end{abstract}

Keywords: e-learning, COVID-19, Ghana, generalized linear models

Received: 13 Sep. $2021 \bullet$ Accepted: 9 Dec. 2021

\section{INTRODUCTION}

Electronic learning encompasses all forms of technology-assisted online learning platforms explored by individuals and institutions in the delivery of teaching and learning as well as creating the medium for access to resource materials and content interaction between students and the instructors (Delen \& Liew, 2016). The global pandemic of COVID-19 undoubtedly has affected many human activities including education (Mouchantaf, 2020). As part of measures to contain the spread of COVID-19, many educational institutions closed school and halted face-to-face teaching and learning (Gupta et al., 2020). The pandemic disrupted many systems especially those that had lost their relevance (Li \& Lalani, 2020)

Many universities across the globe are vigorously moving onto these electronic learning means fully or partially for many useful purposes including giving unlimited access to education to many outside the institution's campus, promoting flexibility in the teaching and learning process as well as decongesting the usually packed lecture halls during active academic seasons (Hadullo et al., 2018; Luna et al., 2017). Way back in 2001, an example is seen of the Massachusett Institute of Technology (MIT) academic departments who decided to host teaching and learning material covering over 2,300 courses to reach over 200 million students and researchers across the globe (Yvonne, 2016). These and related advantages of online platforms lead to the empowerment of learners and faculty in their academic and research activities (Vidakis \& Charitakis, 2018).

Online teaching and learning technology have some advantages over the traditional face-to-face methods by enhancing the capacity of both learners and instructors (Alfraih \& Alanezi, 2016). It arguably a more efficient and reliable means of knowledge sharing covering unlimited boundaries and brings immense improvement in education and training across the globe (Vidakis \& Charitakis, 2018). Other notable advantages of online learning include convenience and flexibility (Tetteh, 2016), provision of a conducive atmosphere for efficient and effective corporate training as well as lifelong access to learning resources (Turban et al., 2015) and reduces the time of teaching and learning by $50 \%$ (Garrison, 2017). Irrespective of the listed 
and many more unlisted benefits of online teaching and learning systems, if our students fail to adapt or ill-perceive it, we will lose the enormous benefits (Tarhini, 2017). It is widely established that the success of online teaching and learning systems largely depends on the level of acceptance of students (Al-Qirim, 2018; Turban et al., 2015). A very important finding by Dodge et al. (2009) and Patterson and McFadden (2009) to the effect that e-learning systems record high drop-out rate than the traditional face-to-face system should be relevant today in providing the needed support for our students to enhance participation and improved acceptance.

With the COVID-19 induced closure of schools in Ghana on the 15th of March 2020, Information and Communication Technologies (ICTs) became increasingly widespread throughout the education sector in Ghana in our quest to limit the spread of the novel coronavirus (Cromwell, 2020). University activities were hard hit by the necessary closure and deprived students of their expected progression plans and aspirations (UNESCO, 2020). Pragmatic steps were therefore taken by managers of our universities to respond to the emergency brought upon the education system by COVID-19 restrictions. It is clear that even in the post-COVID university education in Ghana, ICTs shall remain the most assuring means for distance tuition and a complement to the very old lecturer-controlled face-to-face on-campus teaching and learning (Hailes \& Reza, 2002; Sue et al., 2003).

With the enormous challenges faced by university students involved in online teaching and learning, the National Union of Ghana Students (NUGS) petitioned the ministry of Education to address the numerous critical challenges or halt ongoing online means of teaching and learning (Anyorigya, 2020). They cited the cost of internet bundles on students as an extreme burden, the absence of a proper framework for the rolling out of the online learning system, and above all the many students left behind due to their inability to afford access devices. A survey by Sarpong (2020) and the Centre for Social Science Research (CSSR) of the Kumasi Technical University also revealed that 93\% of final year university students were wishing to return to school for the face-to-face system due to confirmed challenges earlier raised by the student's association. These initial challenges are not limited to the Ghanaian educational system alone but a predominant challenge in many parts of Sub-Saharan Africa (Asunka, 2008).

Way back in 2012, UNESCO (2012) reported the existence of a huge gap between ICT infrastructure and the ability to develop nations to integrate ICT in their efforts at growing their various economies. In that same report, institutions of higher learning in Africa were found to be lacking the ability to integrate ICT even into the school system. The clear presence of limited ICT resources and capacity will require that governments and all stakeholders find sustainable solutions that will be able to transform such challenges into opportunities for schools and the entire economy. In a very recent publication, Maphosa (2021) examines the perception of tertiary students on e-learning technologies deployed COVID-19 and the key factors regarding their usage. Efforts and performance expectancy, and facilitating conditions had positive impact on the behavior intentions of students use of the Moodle virtual class platform. Thus, the students had a positive perception of online learning. It was also established that absence of technology devices and high cost of internet data remains key impediment to e-learning (Maphosa, 2021).

According to Gupta et al. (2020), access to internet and e-learning devices has led to many students not able to get onto e-learning platforms. That notwithstanding, the success of e-learning will require that students accept to adventure even with their little knowledge in online technology (Tam \& El-Azar, 2020) and avert their minds away from the traditional face-to-face mode of teaching and learning (Gelles et al., 2020). Many other known factors affecting e-learning acceptance and adoption includes high-cost ICT devices (Oyediran et al., 2020). Most students therefore prefer blended mode of teaching and learning (Akuratiya \& Meddage, 2020).

The good news is that many institutions of higher learning in Ghana have expanded the e-learning infrastructure considerably in response to the initial challenges. However, more needs to be done in the aspect of timely and continuous monitoring and evaluation of the current infrastructure. The need to offer support and guidance to the many students and staff participating in online teaching and learning is paramount (Kizilcec et al., 2017; Terras \& Ramsay, 2015). This study, therefore, holds the view that managers of our universities will need empirical evidence on how students perceive the adequacy or otherwise of their efforts to enable them to offer the required timely interventions and provide the basis of improvement actions.

To date, most of the discussions at the Kumasi Technical University on e-learning have focused on ways the lecturer can incorporate the new technology into their teaching. From the student perspective, feedback about e-learning seems very sparse. However, there are reports of students from other universities in Europe who prefer to take classes using e-learning overwhelmingly, rather than a traditional course. This study presents empirical evidence of factors that influences the perceptions (positive or negative) of student in respect of the adoption of online teaching and learning using the case of students of the Kumasi Technical University as a test case.

\section{MATERIALS AND METHOD}

\section{Study Design}

This study is a quantitative study based on a structured questionnaire. The unit of analysis consists of 2,000 undergraduate students of the Kumasi Technical University (KsTU). Since schools were closed and students were at home due to COVID-19, the study adopted a convenient sampling method. This sampling technique is popular in most studies investigating technology acceptance (Tarhini et al., 2014). The questionnaire was made available as an online survey link using Google Forms. Web-form link was published in many WhatsApp groups and sent to Facebook messengers of many known undergraduate students of KsTU.

\section{Sample Size}

According to Bougie and Sekaran (2016), a sample size greater than 30 and equal to 500 is appropriate for most scientific empirical social science research since it achieves sufficient statistical power required in social science research. Fortunately, after careful treatment of missing data and exclusion of incomplete responses, 2,000 cases were retained for data analysis. Participation in the survey was voluntary; no financial or other motivation was offered. Web responses were imported into the IBM-SPSS version 25 for cleaning and analysis.

\section{Data Analysis}

Factor analysis was used to measure the perception of students towards e-learning from our 10-item scale. Perceptions with 
Eigenvalues above 1.0 shall be selected. The varimax rotation method is used in the analysis for its advantage of maximizing the variance of the factor loadings. Also, the principal component method is explored in extracting the factors. KMO sampling adequacy test as well as Barlett's test of sphericity, are used to validate the factor model. SPSS version 25 was used in performing the factor analysis. After measurement of the perception of students towards e-learning, a Gaussian generalized linear model (GLM) is used to examine the key student characteristics that influence their perceptions. The two models to be examined are as follows:

1. Positive Perception $\sim$ Gender + Age + Level + Tuition mode + Online platform + Internet provider + internet connectivity

2. Negative Perception $\sim$ Gender + Age + Level + Tuition mode + Online platform + Internet provider + internet connectivity

GLM is an extension of the linear regression model with several useful applications in various fields of research (Lee et al., 2018; Sarpong et al., 2020, 2021a, 2021b), where the random elements are now allowed to belong to a one-parameter exponential family of distributions that includes the normal Gaussian distribution. It has been widely applied in many research studies in selecting predictors of response variables. The goodness-of-fit assessment is similar to the residual assessment in the linear regression case, except that in the case of GLM's, standardization of residuals is required. The Albatross analytics software was used in fitting the GLM model and its diagnostics.

\section{RESULTS}

\section{Description Statistics}

From Table 1, out of the 2,000 student participants, 1,139 were males $(57 \%)$ and 861 were female (43\%). The two dominating groups were those 1,442 respondents aged 20-25 years making up about $72.1 \%$ of the respondents, and the 341 (17.1\%) students between the ages of 26-30 years of age. The majority of our student participants were from the Kumasi Technical University Institute of Distance and Continuing education - IDCE. They make up $44.2 \%$ of the total respondents, followed by students of the KsTU Business School with 25.6\%. Participation in respect of the level of students was in descending order with level 100 participants having the highest number; 960 (48.0\%), level 200 participants; 572 (28.6\%), level 300 participants; 427 (21.4\%), and only $41(2.1 \%)$ level 400 participants. Students undertaking the regular tuition mode were in a clear majority of 1,118 (55.9\%).

\section{Participation in E-learning}

Results in Table 2 indicate that only about 9.9\% (167) of the students have not participated in any mode of e-learning at the time of this study. Most of these students were in level 100 even though cumulatively, levels 200 and 300 have 49 students more than those inlevel 100 who had not participated in the rolled-out e-learning technologies for teaching and learning at Kumasi Technical University. The non-participating students could be doing so willingly or are denied participation due to e-learning related challenges.

\section{Level of Satisfaction}

Figure 1 reflects students' level of satisfaction with the KsTU elearning so far. It is obvious from the results that students are not satisfied with e-learning. Of the $90.1 \%$ of students who are
Table 1. Descriptive statistics

\begin{tabular}{|c|c|c|c|}
\hline Items & & Frequency & Percent \\
\hline \multirow{2}{*}{ Gender } & Male & 1,139 & 57.0 \\
\hline & Female & 861 & 43.1 \\
\hline \multirow{5}{*}{ Age } & Less than 20 & 121 & 6.1 \\
\hline & $20-25$ & 1,442 & 72.1 \\
\hline & $26-30$ & 341 & 17.1 \\
\hline & $31-35$ & 63 & 3.2 \\
\hline & $36+$ & 33 & 1.7 \\
\hline \multirow{8}{*}{ Faculty } & Business School & 511 & 25.6 \\
\hline & Applied Science & 122 & 6.1 \\
\hline & Health Sciences & 163 & 8.2 \\
\hline & Engineering & 164 & 8.2 \\
\hline & Creative Arts and Technology & 64 & 3.2 \\
\hline & FEED & 19 & 1.0 \\
\hline & IDCE & 883 & 44.2 \\
\hline & Built and Natural Env. & 74 & 3.7 \\
\hline \multirow{4}{*}{ Level } & 100 & 960 & 48.0 \\
\hline & 200 & 572 & 28.6 \\
\hline & 300 & 427 & 21.4 \\
\hline & 400 & 41 & 2.1 \\
\hline \multirow{3}{*}{ Mode } & Regular & 1,118 & 55.9 \\
\hline & Evening & 689 & 34.5 \\
\hline & Weekend & 193 & 9.7 \\
\hline Total & & 2,000 & 100.0 \\
\hline
\end{tabular}

Table 2. Participation in e-learning

\begin{tabular}{|c|c|c|c|c|}
\hline \multirow[t]{2}{*}{ Items } & & \multicolumn{2}{|c|}{$\begin{array}{l}\text { Have you ever participated in } \\
\text { the e-learning platforms of KsTU }\end{array}$} & \multirow[t]{2}{*}{ Total } \\
\hline & & Yes & No & \\
\hline \multirow{8}{*}{ Faculty } & Business School & 466 & 45 & 511 \\
\hline & Applied Science & 103 & 19 & 122 \\
\hline & Health Sciences & 158 & 5 & 163 \\
\hline & Engineering & 150 & 14 & 164 \\
\hline & $\begin{array}{l}\text { Creative Arts and } \\
\text { Technology }\end{array}$ & 53 & 11 & 64 \\
\hline & IEED & 17 & 2 & 19 \\
\hline & IDCE & 786 & 97 & 883 \\
\hline & Built and Natural Env. & 70 & 4 & 74 \\
\hline \multirow{4}{*}{ Level } & 100 & 890 & 70 & 960 \\
\hline & 200 & 518 & 54 & 572 \\
\hline & 300 & 362 & 65 & 427 \\
\hline & 400 & 33 & 8 & 41 \\
\hline \multirow{3}{*}{ Mode } & Regular & 1,018 & 100 & 1,118 \\
\hline & Evening & 610 & 79 & 689 \\
\hline & Weekend & 175 & 18 & 193 \\
\hline Total & & 1,803 & 197 & 2,000 \\
\hline
\end{tabular}

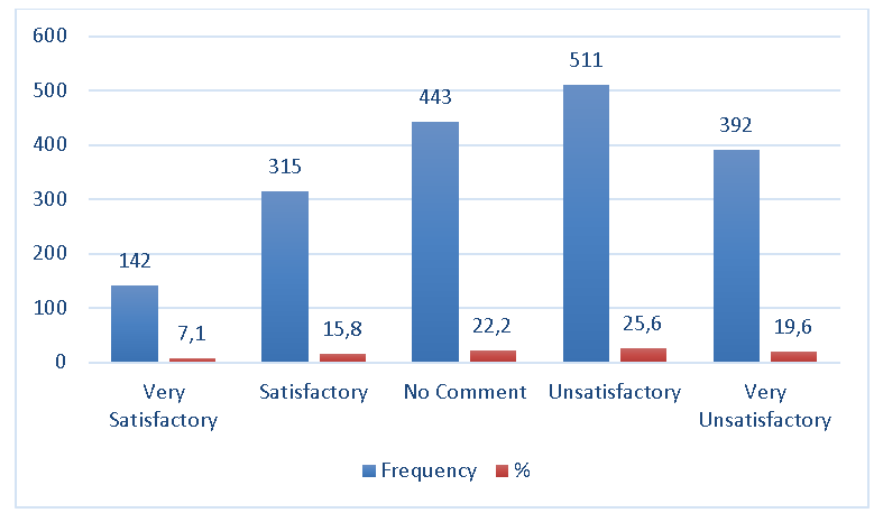

Figure 1. Students level of satisfaction with online delivery so far 
participating, less than $23 \%$ indicated that they are Very Satisfied or Satisfied with the ongoing e-learning. This means that majority of the students are not satisfied. 45.2\% expressed that they are Unsatisfied or Very Unsatisfied with e-learning. It appears that even though students admit that they need to continue learning despite the closure of schools, they were themselves unprepared for the e-learning, and additionally, they were not oriented by the University before the commencement of the e-learning.

\section{Students Challenges with E-learning}

The two major challenges facing student participation in the ongoing e-learning include; poor network connectivity and the high cost of internet data. Other challenges worthy of note include lack of a well-structured timetable moderate the teaching and learning vi elearning, unstable electricity to power the entire concept of e-learning, and lack of infrastructural support from the university's ICT directorate as evident in Table 3.

Table 3. Challenges with e-learning

\begin{tabular}{ccc}
\hline & Challenges facing the online delivery system & Frequency \\
\hline & Unstable electricity & 76 \\
\cline { 2 - 3 } Valid & Unable to afford cost of internet data & 331 \\
\cline { 2 - 3 } & Poor network connectivity & 370 \\
\cline { 2 - 3 } & Lack of infrastructural support from ICT Directorate & 74 \\
\cline { 2 - 3 } & Absence of a suitable time table & 123 \\
\hline Other challenges & 983 \\
\hline
\end{tabular}

\section{Students E-learning Preferences}

From Table 4, student preferred e-learning platform, internet data provider, and assessment of internet connectivity are reported. Zoom meeting platform was the most preferred e-learning platform by students $(936 ; 46.8 \%)$. Followed by the model v-class e-learning platform $(478 ; 23.9 \%)$. According to the respondents, though a bit expensive compared to the University's virtual classroom, accessing zoom is easy and it is user-friendly. Again, the University's virtual classroom coming as the second most preferred e-learning medium by students is a good sign suggesting that when students understand how to use it and appreciate its functionality, preference and usage could increase, and outdo the use of other mediums. WhatsApp and video recording ware also preferred to be 280 (14.0\%) and 230 (11.5\%), respectively.

Table 4. E-learning preferences

\begin{tabular}{cccc}
\hline Item & & Frequency & Percent \\
\hline \multirow{3}{*}{\begin{tabular}{c} 
Most preferred e-learning platform \\
\cline { 2 - 4 }
\end{tabular}} & Moodle V Class & 478 & 23.9 \\
\cline { 2 - 4 } & Zoom & 936 & 46.8 \\
\cline { 2 - 4 } data & WhatsApp & 280 & 14.0 \\
\cline { 2 - 4 } & Video Recording & 230 & 11.5 \\
\cline { 2 - 4 } & any other & 76 & 3.8 \\
\hline \multirow{2}{*}{$\begin{array}{c}\text { Network chosen for KsTU internet } \\
\text { Internet connectivity at your } \\
\text { current location? }\end{array}$} & MTN & 1655 & 82.8 \\
\cline { 2 - 4 } & Vodafone & 345 & 17.3 \\
\cline { 2 - 4 } & Poor & 561 & 28.1 \\
\cline { 2 - 4 } & Average & 965 & 48.3 \\
\hline Total & Good & 474 & 23.7 \\
\hline
\end{tabular}

Further interrogation revealed that $72 \%$ of the students experienced between Average and Good internet connectivity. Quality internet (fast and reliable) is essential for e-learning. It is also commendable that even the $28 \%$ who experience poor internet connectivity make that much effort to participate in e-learning. It is expected that despite the quality of internet connectivity students grapple with if challenges are adequately addressed, an increase in participation is expected.

\section{Perception of Students Towards E-learning}

The factor analysis uses 10 items to measure the perception of students towards e-learning. It identifies two major perceptions with eigenvalues above 1.0. the varimax rotation method used in the analysis has the advantage of maximizing the variance of the loadings. Also, a principal components method was employed to extract factors. The factor structure of the two factors accounted for $56.58 \%$ of the variance. Since the KMO measure of sampling adequacy in Table 5 was 83.3, the factor analysis was considered a useful validation of the factor model. Barlett's test of sphericity was $6,115.073(\mathrm{p}<0.000)$, indicating that one or more factors exist. The reliability values within the five domains were .813 and .791 , indicating adequacy criteria for internally consistent measurement. Thus, the values indicate the internal consistency of items on each domain.

Table 5. KMO and Bartlett's test

\begin{tabular}{|c|c|c|}
\hline \multicolumn{2}{|c|}{ Kaiser-Meyer-Olkin measure of sampling adequacy } & .833 \\
\hline \multirow{3}{*}{ Bartlett's test of sphericity } & Approx. Chi-square & $6,115.073$ \\
\hline & $\mathrm{df}$ & 45 \\
\hline & Sig. & .000. \\
\hline
\end{tabular}

Table 6 shows factor structure of student's perception towards elearning in Ghana. Factor loadings ranged from .648 to .830 on the two domains. Since the cut-off for the size of loading and its interpretation depend on the researcher's preference (Tabachnick \& Fidell, 2007), this study set .40 as the cut-off size of loadings. Meanwhile, communalities for each variable were from .446 to .701 , with each variable contributing to establishing two-factor structures or components. These components were labeled: (1) Positive perception, and (2) Negative perception. Dependent variables; Positive perception, and Negative perception were computed from average scores of the variables that come together to constitute them.

\section{Positive Perception Model}

The positive perception model was used to select characteristics that might be influencing their thoughts on e-learning technology in teaching and learning. From the coefficients table (Table 7), the model found no significant influence of gender, student network provider on positive perception expressed by students over the use of e-learning technology. This means that students hold the view that e-learning technology in teaching and learning delivery amid COVID-19 is positive regardless of who you are and what network you subscribe to as a student. There was, however a significant influence of students within the age bracket 31-35 years, those in level 300, those receiving tuition through the regular face-to-face mode before the invasion of COVID-19, those who have practically participated in e-learning through any of the online platforms as well as those suffering from internet connectivity challenges from their places of residence. For a unit change in the influence of each of the significant variables, only 
Table 6. Factor structure of student's perception towards e-learning in Ghana

\begin{tabular}{|c|c|c|c|c|c|c|}
\hline \multirow[t]{2}{*}{ Descriptive statistics } & \multirow[b]{2}{*}{ Mean } & \multirow[b]{2}{*}{ Std. Deviation } & \multicolumn{2}{|c|}{ Communalities } & \multicolumn{2}{|c|}{ Rotated Components } \\
\hline & & & Initial & Extraction & 1 & 2 \\
\hline E-learning gives students a chance to speed up or slow down as and when necessary & 3.07 & 1.286 & 1.000 & .468 & .681 & \\
\hline Students are able to get extra study material from e-learning for their personal development & 2.97 & 1.401 & 1.000 & .517 & .716 & \\
\hline E-learning is more flexible for access anytime, anywhere & 3.04 & 1.474 & 1.000 & .532 & .729 & \\
\hline Travel time and associated costs are reduced or eliminated & 2.78 & 1.406 & 1.000 & .433 & .649 & \\
\hline E-learning provides learning opportunities that are highly flexible & 3.07 & 1.323 & 1.000 & .660 & .807 & \\
\hline Technology tools make collaboration among students much easier & 2.86 & 1.331 & 1.000 & .529 & .727 & \\
\hline Self-study in e-learning can make students feel bored & 2.12 & 1.369 & 1.000 & .680 & & .822 \\
\hline E-learning can make working in teams more difficult & 2.14 & 1.370 & 1.000 & .693 & & .830 \\
\hline E-learning can make students lose motivation in their studies & 2.28 & 1.404 & 1.000 & .701 & & .819 \\
\hline E-learning is limited by how comfortable one is with technology & 2.22 & 1.293 & 1.000 & .446 & & .648 \\
\hline Eigen values & & & & & 3.265 & 2.930 \\
\hline Variance explained & & & & & 32.65 & 23.929 \\
\hline
\end{tabular}

Table 7. Coefficients of positive perception model

\begin{tabular}{|c|c|c|c|c|c|}
\hline Coefficients & & & & & \\
\hline \multirow{2}{*}{ Variables } & & Estimate & Std. Error & t value & $\operatorname{Pr}(>|t|)$ \\
\hline & (Intercept) & 20.69299 & 0.89954 & 23.00394 & 0.00000 \\
\hline \multirow{2}{*}{ Gender } & Female & - & - & - & - \\
\hline & Male & -0.00933 & 0.26167 & -0.03565 & 0.97157 \\
\hline \multirow{5}{*}{ Age } & $20-25$ & - & - & - & - \\
\hline & $26-30$ & -0.69773 & 0.36669 & -1.90278 & 0.05721 \\
\hline & $31-35$ & -2.49045 & 0.79008 & -3.15215 & 0.00164 \\
\hline & $36+$ & -1.70626 & 1.05679 & -1.61457 & 0.10656 \\
\hline & Less than 20 & -0.70959 & 0.55487 & -1.27884 & 0.2011 \\
\hline \multirow{4}{*}{ Level } & 100 & - & - & - & - \\
\hline & 200 & -0.25478 & 0.31037 & -0.82089 & 0.41181 \\
\hline & 300 & -1.04723 & 0.35014 & -2.99089 & 0.00282 \\
\hline & 400 & 0.26322 & 0.99238 & 0.26524 & 0.79085 \\
\hline \multirow{3}{*}{ Tuition mode } & Evening & - & - & - & - \\
\hline & Regular & 0.59474 & 0.28959 & 2.05373 & 0.04013 \\
\hline & Weekend & -0.18513 & 0.55063 & -0.33622 & 0.73674 \\
\hline \multirow{5}{*}{ Online Platform } & Other & - & - & - & - \\
\hline & Moodle V Class & -3.17858 & 0.71555 & -4.44215 & 0.00001 \\
\hline & Video Recording & -1.53265 & 0.7624 & -2.01029 & 0.04454 \\
\hline & Whatsup & -1.98872 & 0.74585 & -2.66639 & 0.00773 \\
\hline & Zoom & -2.50268 & 0.68729 & -3.64139 & 0.00028 \\
\hline \multirow{4}{*}{ Internet Provider } & Airtel/Tigo & - & - & - & - \\
\hline & Glo & -1.03771 & 1.49828 & -0.6926 & 0.48864 \\
\hline & MTN & -0.65516 & 0.56188 & -1.16601 & 0.24375 \\
\hline & Vodafone & -0.27398 & 0.63647 & -0.43047 & 0.6669 \\
\hline \multirow{3}{*}{ Connectivity } & Average & - & - & - & - \\
\hline & Good & -1.11466 & 0.32373 & -3.4432 & 0.00059 \\
\hline & Poor & -2.00616 & 0.30651 & 6.54517 & 0.00000 \\
\hline
\end{tabular}

those receiving tuition through the regular face-to-face mode before the invasion of COVID-19 express a high positive perception over the use of e-learning technology as compared to students within the age bracket 31-35 years, those in level 300, those who have practically participated in e-learning through any of the online platforms as well as those suffering from internet connectivity challenges.

To ensure that the positive perception model has the required quality and goodness of fit, model checking plots as shown in Figure 2 were used. Running means in the plot of residuals against fitted values shows no form of a marked trend indicating model prediction accuracy, plots of absolute residuals have a relatively stable slope indicating that errors are stationary and non-increasing variance function. The normal plots show no discrepancy while the histogram of the residuals shows a symmetric normal plot. These are very good indications of an appropriate and reliable model.

\section{Negative Perception Model}

From the model table (Table 8), there was no significant influence of gender, age, and mode of tuition on negative perceptions expressed by students over the use of e-learning technology. This means that the setbacks of e-learning technology use apply to all regardless of your age, gender, or your mode of tuition. There was, however a significant influence of students in level 300, users of the Moodle VClass platform, subscribers of Glo and MTN network as well as students who encounter poor internet connectivity from their places of residence. For a unit change in the influence of each of the significant variables, level 300 students, and Moodle VClass platform users express a high negative 

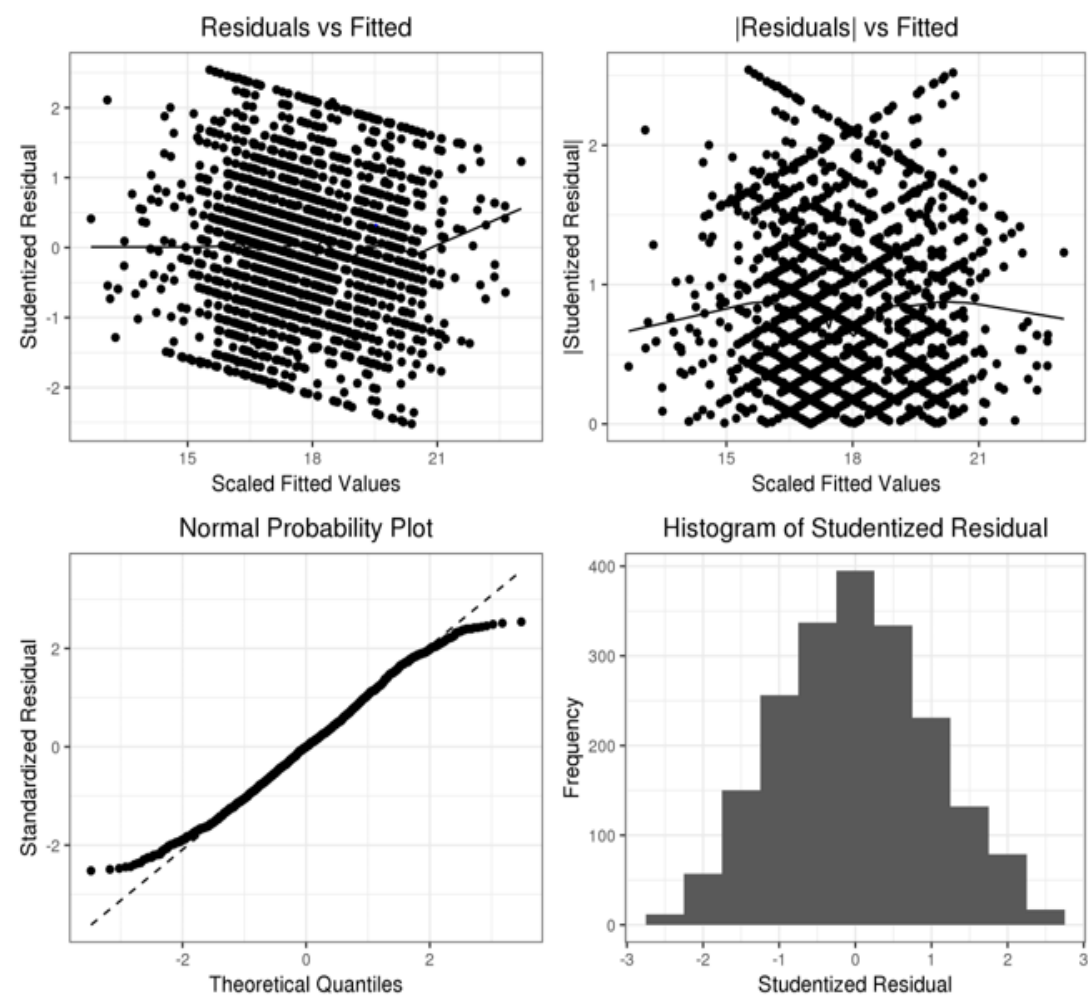

Figure 2. Diagnostic plots for positive perception model

Table 8. Coefficients of negative perception model

\begin{tabular}{|c|c|c|c|c|c|}
\hline \multicolumn{6}{|l|}{ Coefficients } \\
\hline \multirow{2}{*}{ Variables } & & Estimate & Std. Error & t value & $\operatorname{Pr}(>|t|)$ \\
\hline & (Intercept) & 8.82299 & 0.66039 & 13.3602 & 0 \\
\hline \multirow{2}{*}{ Gender } & Female & - & - & - & - \\
\hline & Male & 0.20657 & 0.1921 & 1.07533 & 0.28236 \\
\hline \multirow{5}{*}{ Age } & $20-25$ & - & - & - & - \\
\hline & $26-30$ & 0.24461 & 0.2692 & 0.90865 & 0.36365 \\
\hline & $31-35$ & 0.82066 & 0.58003 & 1.41485 & 0.15727 \\
\hline & $36+$ & 1.51518 & 0.77584 & 1.95296 & 0.05096 \\
\hline & Less than 20 & 0.52097 & 0.40735 & 1.27892 & 0.20107 \\
\hline \multirow{4}{*}{ Level } & 100 & - & - & - & - \\
\hline & 200 & -0.0552 & 0.22785 & -0.24217 & 0.80868 \\
\hline & 300 & 0.89827 & 0.25705 & 3.49449 & 0.00049 \\
\hline & 400 & 0.66517 & 0.72855 & 0.91301 & 0.36135 \\
\hline \multirow{3}{*}{ Tuition mode } & Evening & - & - & - & - \\
\hline & Regular & -0.3477 & 0.2126 & -1.63525 & 0.10216 \\
\hline & Weekend & -0.1986 & 0.40424 & -0.49127 & 0.62329 \\
\hline \multirow{5}{*}{ Online Platform } & Other & - & - & - & - \\
\hline & Moodle V Class & 1.26083 & 0.52532 & 2.40013 & 0.01648 \\
\hline & Video Recording & 0.13404 & 0.55971 & 0.23948 & 0.81075 \\
\hline & Whatsup & 0.55646 & 0.54756 & 1.01626 & 0.30963 \\
\hline & Zoom & 0.75707 & 0.50457 & 1.50043 & 0.13366 \\
\hline \multirow{4}{*}{ Internet Provider } & Airtel/Tigo & - & - & - & - \\
\hline & Glo & -2.524 & 1.09995 & -2.2946 & 0.02186 \\
\hline & MTN & -0.8172 & 0.4125 & -1.98106 & 0.04772 \\
\hline & Vodafone & -0.8701 & 0.46726 & -1.86217 & 0.06273 \\
\hline \multirow{3}{*}{ Connectivity } & Average & - & - & - & - \\
\hline & Good & 0.11095 & 0.23766 & 0.46685 & 0.64066 \\
\hline & Poor & -0.9275 & 0.22502 & -4.12197 & 0.00004 \\
\hline
\end{tabular}

perception over the use of e-learning technology as compared to subscribers of Glo and MTN network as well as students who encounter poor internet connectivity.
Model-checking plots for our negative perception model, as shown in Figure 3, show no form of a marked trend in the running mean of the plot of residuals against fitted values, an indication of model 

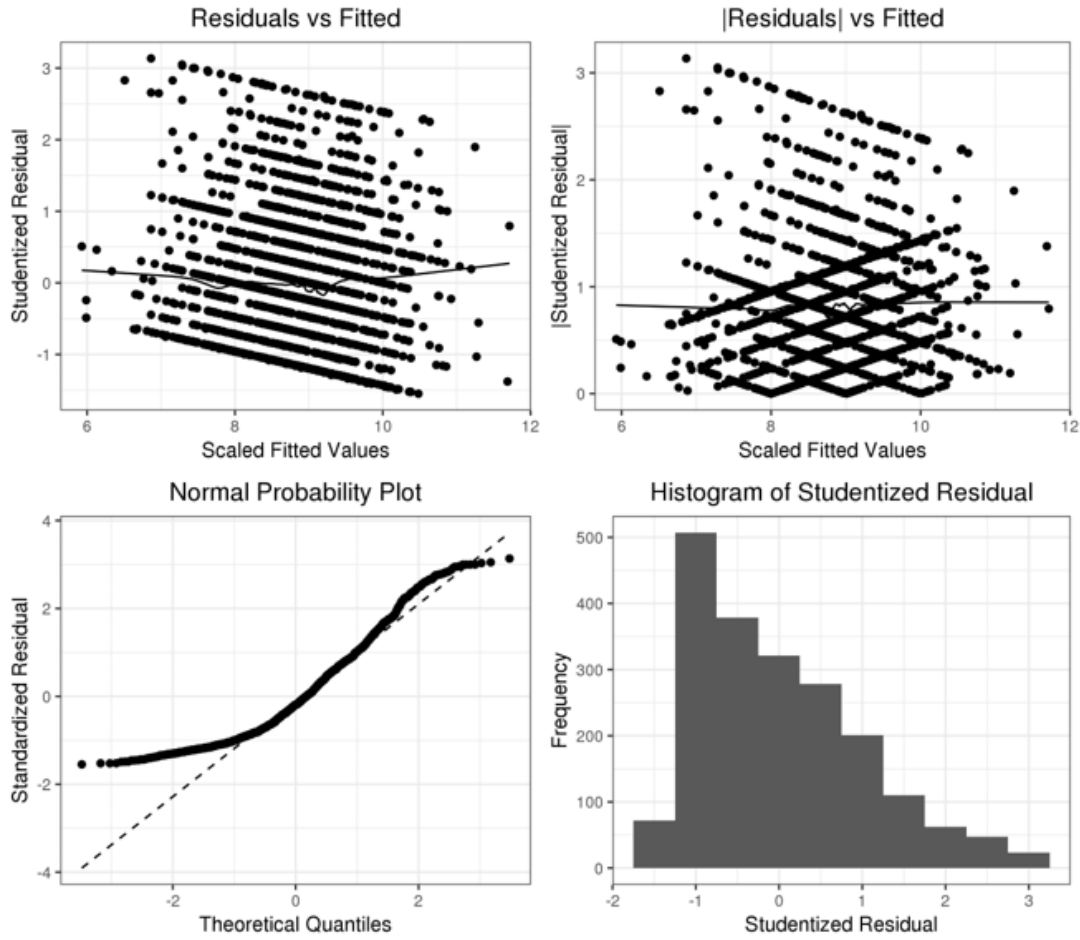

Figure 3. Diagnostic plots for negative perception model

prediction accuracy (Lee et al., 2018; Sarpong et al., 2020; Sarpong et al., 2021a, 2021b). Variance function is non-increasing as evident in the plot of absolute residuals. Though the normal plots and histogram of the residuals show some amount of discrepancy, the large sample used in this study disables the strict assurance of normality assumption. Overall, the negative perception is an appropriate and reliable model.

\section{DISCUSSION}

This study promotes the implementation of e-learning technology in post-COVID-19 teaching and learning by presenting findings from Ghanaian university students' perceptions. It offers an exposition on the extent of willingness to participate, level of satisfaction as well as some key challenges facing Ghanaian students in their quest to transform from the long-known face-to-face delivery mode onto the online learning platform. With only about $9.9 \%$ (167) of the students not participating in any mode of e-learning at the time of this study, it is abundantly clear that students in higher learning institutions in Ghana are willing to adapt fully to e-learning. The early day's call for a halt and return to school for face-to-face (Anyorigya, 2020; Sarpong, 2020) was a demonstration of frustration resulting from the many teething challenges that characterized the abrupt shift to online teaching and learning due to COVID-19 schools closure.

It is the case in many developing countries that online technology for teaching and learning is still facing challenges, and Ghana is no exception (Antwi, 2018). Key amongst those challenges as reported by this study include lack of access to technology devices, unstable electricity, high cost of internet data, poor internet network, absence of infrastructural support from the Kumasi Technical University ICT directorate, and absence of a suitable timetable to guide online teaching and learning. Many studies have found similar challenges facing elearning in many jurisdictions. For example, Hamajoda (2018) believed that standby generators and solar power be supplied to educational institutions to help facilitate e-learning, especially in rural areas. Other researchers such as Aboagye et al. (2020) and Maphosa (2020) also reveals that many students were having difficulty shifting onto elearning mode due because they did not have computers, laptops, and tablets. The absence of infrastructural support from the university's ICT directorate will be a great setback to the successful implementation of online teaching and learning. Offering timely assistance and training to users has been found to promote successful transition and e-learning integration among students (Alhabeeb \& Rowley, 2018; Muhammad et al., 2017; Solangi et al., 2018).

The cost of internet data to support online teaching and learning will need great attention from university managements. Students may have to bear extra costs aside from their tuition fees or universities will have to charge an online fee to provide stable and reliable internet data for use (Adarkwah, 2021; Piña et al., 2018). In Malaysia, Ramli et al. (2020) reports that high data costs hindered learners from fully participating in online learning. Aboagye et al. (2020) also reported that with many parents temporarily out of job due to COVID-19 restrictions, students struggled to buy internet data to support elearning.

Also, a suitable and flexible timetable for e-Teaching and eLearning makes users comfortable with the e-learning and helps to enhance student's self-efficacy and foster smooth adaptation to online learning (Adarkwah, 2021; Alhabeeb \& Rowley, 2018; Piña et al., 2018; Ramli et al., 2020; Solangi et al., 2018). From the positive perception model, only those receiving tuition through the regular face-to-face mode before the invasion of COVID-19 express a high positive perception over the use of e-learning technology. Those already into some form of distance learning are not too enthused about the movement to e-learning mode. The model found no significant influence of gender, and network providers on positive perception expressed by students over the use of e-learning technology. This 
means that students hold the view that e-learning technology in teaching and learning delivery amid COVID-19 is positive regardless of who you are and what network you subscribe to as a student. This view is supported by Maphosa, 2021 who examined the perception of tertiary students on e-learning technologies deployed under COVID-19 and concluded that students had a positive perception of online learning.

In another vein, the negative perception model highlights Moodle VClass platform users as having a high negative perception over the use of e-learning technology. There was no significant influence of gender, age, and mode of tuition on negative perceptions expressed by students over the use of e-learning technology. This means that the setbacks of e-learning technology use apply to all regardless of your age, gender, or your mode of tuition. All these key findings of this study point to the need for a well-coordinated action plan by universities and the Ghana government toward consolidating online technology infrastructure to support the new normal.

\section{CONCLUSIONS}

What is clear from this study is that online learning in Ghana faces a lot of challenges. Many students hold the view that e-learning technology in teaching and learning delivery amid COVID-19 is positive regardless of who you are and what network you subscribe to as a student. Also, setbacks of e-learning technology use apply to all regardless of your age, gender, or mode of tuition. In all, this study adds value to the body of literature already existing on the subject of online learning in the context of Ghana amidst the global COVID-19 pandemic. Overall, insights from this study should afford university managers and policymakers measures to help address these challenges to enhance the smooth transition to full or partial teaching and learning using online technology.

Immediate recommendations from this study will include; the establishment of e-learning centers to provide supports for e-learning only, as well as the institution of special IT skill training and orientation for all students. Also, university managers may liaise with central governments to procure assistive IT devices for students to enhance their full participation. Finally, a dedicated team should be put in place by university managers to swiftly provide routine assistance and support to students and other users of all e-learning platforms in use. As further studies, authors are currently investigating e-learning from the Lecturers point of view. Other areas of interest in future research may be to investigate the central government's action plan for elearning in institutions of higher learning as well as an investigation into the effects of e-learning challenges outlined in this study on student's overall performance.

Author contributions: SAS: Conceptualization, methodology, software, validation, formal analysis, investigation, resources, data curation, writingoriginal draft preparation, writing-review and editing, supervision, project administration; IO-A: Methodology, investigation, resources, project administration; EKB: Conceptualization, resources, writing-review and editing; GD: Methodology, validation, resources, writing-review and editing. All authors have read and agreed to the published version of the manuscript.

Funding: The authors received no financial support for the research and/or authorship of this article.

Declaration of interest: Authors declare no competing interest.
Data availability: Data generated or analysed during this study are available from the authors on request.

\section{REFERENCES}

Aboagye, E., Yawson, J. A., \& Appiah, K. N. (2020). COVID-19 and elearning the challenges of students in tertiary institutions in Ghana. Social Education Research, 2(1), 109-115. https://doi.org/10.37256/ ser.122020422

Adarkwah, M. A. (2021). I'm not against online teaching, but what about us? ICT in Ghana post-COVID-19. Education and Information Technologies, 26, 1665-1685. https://doi.org/10.1007/s10639-02010331-z

Akuratiya, D. A., \& Meddage, D. N. R. (2020). Students' perception of online learning during COVID-19 pandemic: A survey study of IT students. International Journal of Research and Innovation in Social Science, 4(9), 775-778. https://doi.org/10.21203/rs.3.rs-41178/v1

Alfraih, M. M., \& Alanezi, F. S. (2016). Accounting students' perceptions of effective faculty attributes. Journal of International Education in Business, 9, 123-142. https://doi.org/10.1108/JIEB-042016-0004

Alhabeeb, A., \& Rowley, J. (2018). E-learning critical success factors: Comparing perspectives from academic staff and students. Computers \& Education, 127, 1-12. https://doi.org/10.1016/ j.compedu.2018.08.007

Al-Qirim, N., Rouibah, K., Tarhini, A., Serhani, M. A., Yammahi, A. R., \& Yammahi, M. A. (2018). Towards a personality understanding of information technology students and their IT learning in UAE university. Education and Information Technologies, 23, 29-40. https://doi.org/10.1007/s10639-017-9578-1

Antwi, S., Bansah, A. K., \& Franklin, T. (2018). The information technology challenges in teaching senior high school geography in Ghana. Issues and Trends in Educational Technology, 6(1), 16-37. https://doi.org/10.2458/azu_itet_v6i1_antwi

Anyorigya, D. A. (2020). COVID-19: Halt challenge-ridden online learning in universities - NUGS to Government. https://citi newsroom.com/2020/04/covid-19-halt-challengeridden-onlinelearning-in-universities-nugs-to-government/

Asunka, S. (2008). Online learning in higher education in sub-Saharan Africa: Ghanaian university students' experiences and perceptions. International Review of Research in Open and Distance Learning, 9(3), 1-23. https://doi.org/10.19173/irrodl.v9i3.586

Bougie, R., \& Sekaran, U. (2016). Research methods for business: A skillbuilding approach (7th Ed.). John Wiley \& Sons.

Cromwell, A. (2020). Education Ministry set to release an online learning platform for senior high schools. https://www.myjoyonline.com/ news/national/education-ministry-set-torelease-online-learningplatform-for-senior-high-schools/

Delen, E., \& Liew, J. (2016). The use of interactive environments to promote self-regulation in online learning: A literature review. European Journal of Contemporary Education, 15(1), 24-33. https://doi.org/10.13187/ejced.2016.15.24 
Dodge, T. M., Mitchell, M. F., \& Mensch, J. M. (2009). Student retention in athletic training education programs. Journal of Athletic Training, 44(2), 197-207. https://doi.org/10.4085/1062-605044.2.197

Garrison, D. R. (2017). E-learning in the 21st century: A community of inquiry framework for research and practice (3rd Ed.). Routledge/Taylor and Francis.

Gelles, L. A., Lord, S. M., Hoople, G. D., Chen, D. A., \& Mejia, J. A. (2020). Compassionate flexibility and self-discipline: Student adaptation to emergency remote teaching in an integrated engineering energy course during COVID-19. Education Sciences, 10(11). https://doi.org/10.3390/educsci10110304

Gupta, M. M., Jankie, S., Pancholi, S. S., Talukdar, D., Sahu, P. K., \& Sa, B. (2020). Asynchronous environment assessment: A pertinent option for medical and allied health profession education during the COVID-19 pandemic. Education Sciences, 10(12), 352 https://doi.org/10.3390/educsci10120352

Hadullo, K., Oboko, R., \& Omwenga, E. (2018). Status of e-learning quality in Kenya: Case of Jomo Kenyatta University of agriculture and technology postgraduate students. International Review of Research in Open and Distance Learning, 19(1), 138-159. https://doi.org/10.19173/irrodl.v19i1.3322

Hailes, S., \& Reza H. (2002). The digital university-Building a learning community. Springer.

Hamajoda, A. (2018). Towards a topology for ICT and e-learning in Nigerian rural public primary schools. https://www.semantic scholar.org/paper/Towards-a-Topology-for-ICT-\%26-Elearning-in-Nigerian-Hamajoda/f42aa204fcdd30a6fade81cb62481 d8186706a24

Kizilcec, R. F., Pérez-Sanagustín, M., \& Maldonado, J. J. (2017). Selfregulated learning strategies predict learner behavior and goal attainment in massive open online courses. Computers in Education, 104, 18-33. https://doi.org/10.1016/j.compedu.2016.10.001

Lee, Y., Nelder, J. A., \& Pawitan, Y. (2018). Generalized linear models with random effects: Unified analysis via H-likelihood. Routledge. https://doi.org/10.1201/9781315119953

Li, C., \& Lalani, F. (2020). The COVID-19 pandemic has changed education forever. This is how. https://www.weforum.org/agenda/2020/04/ coronavirus-education-global-COVID19-online-digital-learning/

Luna, J. M., Castro, C., \& Romero, C. (2017). MDM tool: A data mining framework integrated into Moodle. Computer Applications in Engineering Education, 25(1), 90-102. https://doi.org/10.1002/ cae. 21782

Maphosa, V. (2021). Factors influencing student's perceptions towards e-learning adoption during COVID-19 pandemic: A developing country context. European Journal of Interactive Multimedia and Education, 2(2), e02109. https://doi.org/10.30935/ejimed/11000

Maphosa, V., Jita, T., \& Dube, B. (2020). Students' perception and use of Moodle as the e-learning system implemented at a rural university in Zimbabwe. In EdMedia and Innovate Learning (pp. 175182). Association for the Advancement of Computing in Education.

Mouchantaf, M. (2020). The COVID-19 pandemic: Challenges faced and lessons learned regarding distance learning in Lebanese higher education institutions. Theory and Practice in Language Studies, 10(10), 1259-1266. https://doi.org/10.17507/tpls.1010.11
Muhammad, G., Albejaidi, F. M., \& Akhtar, R. (2017). Challenges in the development of eLearning systems in higher education of the developing countries. London Journal of Research in Humanities and Social Sciences, 17(2), 13-32.

Oyediran, W. O, Omoare, A. M., Owoyemi, M. A., Adejobi, A. O., \& Fasasi, R. B. (2020). Prospects and limitations of e-learning application in private tertiary institutions amidst COVID-19 lockdown in Nigeria. Heliyon, 6(11), 5450-5457. https://doi.org/ 10.1016/j.heliyon.2020.e05457

Patterson, B., \& McFadden, C. (2009). Attrition in online and campus degree programs. Online Journal of Distance Learning Administration, 12(2), 1-8.

Piña, A. A., Lowell, V. L., \& Bruce, R. H. (2018). Leading and managing e-learning. Springer. https://doi.org/10.1007/978-3-319-61780-0

Ramli, M., Majid, M., \& Badyalina, B. (2020). Impeding factors towards the effectiveness of online learning during COVID-19 pandemic among social. International Journal of Learning and Development, 10(4), 37-49. https://doi.org/10.37256/ser.122020422

Sarpong, S. A. (2020). We want to go back to school; $93 \%$ of final year university students demand. Daily Heritage Newspaper, http://dailyheritage.com.gh/?p=28878

Sarpong, S. A., Avuglah, R. K., \& Nsowah-Nuamah, N. N. N. (2020). Application of joint generalized linear models in determining physical support factors that influence crop yield in Northern Ghana. Universal Journal of Agricultural Research, 8(4), 124-130. https://doi.org/10.13189/ujar.2020.080404

Sarpong, S. A., Donkoh, R. F., Konnuba, J. K., Ohene-Agyei, C., \& Lee, Y. (2021). Analysis of PM2. 5, PM10, and total suspended particle exposure in the tema metropolitan area of Ghana. Atmosphere, 12(6), 700. https://doi.org/10.3390/atmos12060700

Sarpong, S. A., Sarpong, A. K., \& Lee, Y. (2021). A model for determining predictors of the MUAC in acute malnutrition in Ghana. International Journal of Environmental Research and Public Health, 18(7), 3792. https://doi.org/10.3390/ijerph18073792

Solangi, Z. A., Shahrani, F. A., \& Pandhiani, S. M. (2018). Factors affecting successful implementation of eLearning: Study of colleges and institutes sector RCJ Saudi Arabia. International Journal of Emerging Technologies in Learning, 13(6), 223-230. https://doi.org/ 10.3991/ijet.v13i06.8537

Sue, C., Hudson, A., \& Steel, J. (2003). The emperor's new clothes: Globalization and e-learning in higher education. British Journal of Sociology of Education, 24, 39-53. https://doi.org/10.1080/ 01425690301914

Tabachnick, B. G., \& Fidell, L. S. (2007). Using multivariate statistics (5th Ed.). Allyn \& Bacon/Pearson Education.

Tam, G., \& El-Azar, D. (2020). 3 ways the coronavirus pandemic could reshape education. https://www.weforum.org/agenda/2020/03/ 3 -ways-coronavirus-is-reshaping-education-and-what-changesmight-be-here-to-stay/

Tarhini, A., Hone, K., \& Liu, X. (2014). The effects of individual differences on e-learning users' behavior in developing countries: A structural equation model. Computers in Human Behaviour, 41, 153-163. https://doi.org/10.1016/j.chb.2014.09.020 
Tarhini, A., Masa'deh, R. E., Al-Busaidi, K. A., Mohammed, A. B., \& Maqableh, M. (2017). Factors influencing students' adoption of elearning: A structural equation modeling approach. Journal of International Education in Business, 10(2), 164-182. https://doi.org/10.1108/JIEB-09-2016-0032

Terras, M. M., \& Ramsay, J. (2015). Massive open online courses (MOOCs): Insights and challenges from a psychological perspective. British Journal of Educational Technology, 46(3), 472-487. https://doi.org/10.1111/bjet.12274

Tetteh, G. A. (2016). Effects of business school student's study time on the learning process. Journal of International Education in Business, 9(2), 90-110. https://doi.org/10.1108/JIEB-06-2016-0012

Turban, E., David K., Lee, J. K., Liang, T.-P., \& Turban, D. C. (2015). E-commerce: Mechanisms, platforms, and tools. Springer Cham. https://doi.org/10.1007/978-3-319-10091-3_2
UNESCO. (2012). ICT-enhanced teacher standards for Africa (ICTeTSA). Addis Ababa UNESCO-IICBA. https://unesdoc. unesco.org/ark:/48223/pf0000216105_eng

UNESCO. (2020). COVID-19 educational disruption and response. https://en.unesco.org/covid19/education/response/

Vidakis, N., \& Charitakis, S. (2018). Designing the learning process: The IOLAOS platform. In Proceedings of the 10th International Conference on Subject-Oriented Business Process Management (pp. 111). https://doi.org/10.1145/3178248.3178254

Yvonne, N. (2016). MIT open course ware celebrates 15 years of open sharing. http://news.mit.edu/2016/mit-opencoursewarecelebrates-15-years-open-sharing-0404 